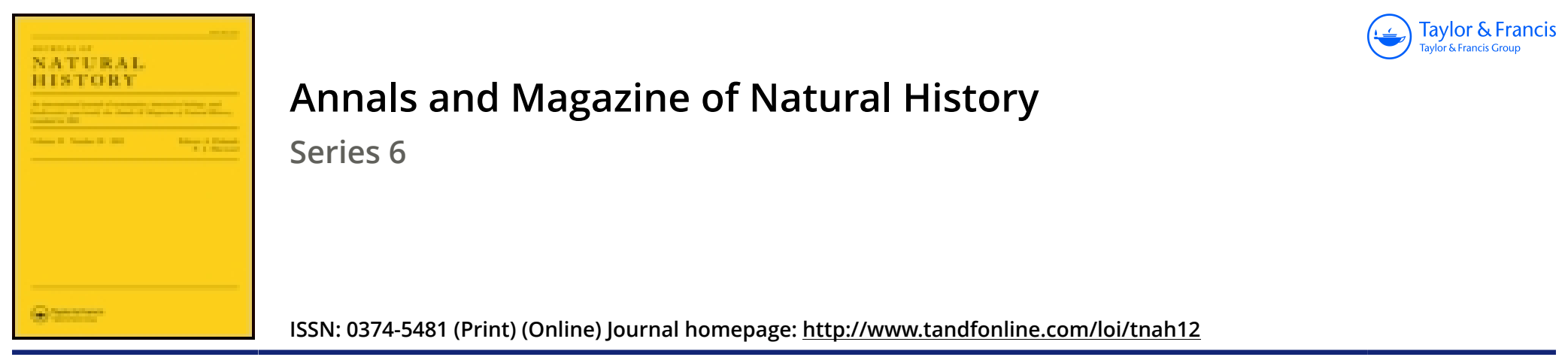

\title{
LI.-On Odonata from the province of Szechuen, in Western China, and from Moupin, in Eastern Thibet
}

\section{Robert M'Lachlan F.R.S.}

To cite this article: Robert M'Lachlan F.R.S. (1896) LI._On Odonata from the province of Szechuen, in Western China, and from Moupin, in Eastern Thibet, Annals and Magazine of Natural History, 17:101, 364-374, DOI: 10.1080/00222939608680381

To link to this article: http://dx.doi.org/10.1080/00222939608680381

曲 Published online: 06 Oct 2009.

Submit your article to this journal $\pi$

Џll Article views: 7

Q View related articles $₫$

Citing articles: 3 View citing articles 
LI.-On Odonata from the Province of Szechuen, in Western China, and from Moupin, in Eastern Thibet. By ROBERT M'Lachlan, F.R.S. \&c.

In the Ann. \& Mag. Nat. Hist. for May 1894 I published (pp. 421-436) a notice of Neuroptera from Ta-chien-lu, in Szechuen, received from my friend Mons. René Oberthür. Since then the same kind friend has sent me a further collection from other neighbouring localities in the same province and also from Eastern Thibet. They are principally Odonata, and I do not here propose to notice the few insects of other groups of Neuroptera, neither do I intend to include some few species present in both consignments where there is nothing of interest in connexion with them. In the following pages several new species are described and previously unknown sexes of others, also notes of local and general interest. As previously noticed, the affinities are with Japan and North China.

\section{Subfam. LIBELLULINA.}

\section{Thecadiplax ardens, M'Lach.}

A series of individuals of both sexes from Moupin agree with those previously described from Ta-chien-lu. Furthermore, several specimens taken by my friend Mr. J. J. Walker in the Chusan Archipelago and on the neighbouring coast of China seem also to belong here, independent of the question of specific right or as representing a race of Th. erotica, Selys.

[N.B.-This appears a fitting opportunity for a short statement with regard to Thecadiplax infuscata, Selys, and Th. erotica, var. fastigiata, Selys.

Th. infuscata was originally described by my friend Baron de Selys (Ann. Soc. Ent. Belg. xxvii. p. 90, 1883) from a pair ( $\sigma q)$ in my collection, the female of which had lost the end of the abdomen. Th. erotica, var. $\$$ fastigiata, was noticed at p. 91 of the same volume of the 'Annales.' In both of these the apical portion of the wings is smoky or blackish.

In the same 'Annales' for 1884, p. 40, Baron de Selys doubts whether the individuals described as a variety of the female of erotica under the name fastigiata should not more properly be considered infuscata, and he expresses some 
doubts as to whether the abdomen and head of the original male type of infuscata might not have been accidentally broken off and replaced by that of some other species. It appears to me practically certain that $T h$. infuscata and the var. fastigiata are specifically identical and distinct from erotica. I can state positively that the head and abdomen of the original male of infuscata have never been detached and also that the two small steel-blue spots are present (contrary to what is stated in the original description) and less rudimentary than those in the original female type. Furthermore, I have since received another male agreeing perfectly with the original in wings, genitalia, and appendages, but in this individual the two steel-blue spots are absent.

Thecadiplax is made up of incongruous materials, and it is probable that the large and ponderous Th. baccha, Selys, may form a group by itself; of this the female is at present not known to me, but I possess three males taken by Mr. J. J. Walker in the Chusan Archipelago and vicinity.

Here, also, I allude to the solitary male insect from Tachien-lu mentioned in my former paper (p.432) as "Agrionoptera (?), sp." In this insect there are symmetrically two nervules in the median area of the posterior wings (one forming the inner triangle and one other), and in the same wings the arculus is symmetrically not coincident with the base of the triangle, but placed distinctly (though not distantly) more towards the base. These characters induced me to think of Agrionoptera as a possible, though doubtful, location. Further examination causes me to think its position is near Thecadiplax infuscata, although the characters just alluded to are foreign to such a connexion. The general form is not opposed to such a position: there are only ten antenodals (the last not continuous) ; the extreme apex (after the end of the pterostigma) of all the wings is infuscated, and the genitalia and appendages do not apparently differ from those of $T h$. infuscata. The top of the face is unspotted (the form of the prothorax it is not now possible to define). Whether this be a case of individual aberration, or whether it is indicative of a group in which there is plasticity of neuration as well as of other characters usually considered essential, further materials can alone decide.]

Orthetrum internum, M'Lach.

Orthetrum japonicum, var. internum, M'Lach. Ann. \& Mag. Nat. Hist. May 1894, p. 431.

In my former paper I gave certain characters separating 
this from typical O.japonicum, Uhler. The only one of any importance was that the triangle of the posterior wing appeared to be constantly traversed by a nervule in internum and constantly free from such nervule in japonicum. Having examined more examples, the same rule appears to hold good, and as such a character when constant is regarded as of specific importance, I here quote internum as a species. In some females of japonicum the middle lobe of the labium is dusk $y$. As before, it is difficult to define any differences in the genitalia.

U. internum occurs also in the Khasia Hills and in other localities of the North Indian side of the Himalayas.

\section{Orthetrum melania, Selys.}

A series of examples from Siao-Lou and also from Moupin, the latter showing a still further western extension of the species. The male previously noticed from Ta-chien-lu was highly adult and pulverulent; those now before me are mostly immature, allowing a comparison as to colours and markings with the Japanese types. No differences are apparent in the colouring of the body; it is, however, probable that the dark space at the base of the wings often remains yellowish (not dark brown) in continental examples.

\section{Crocothemis servilia, Drury.}

A series of males from Moupin are remarkable for the very dark, almost brownish, base of the wings, the colour being also sharply delimitated on the posterior wings; the neuration is dark and the apical margin is usually narrowly dusky. I have similar examples from the coast of North China. These examples induced me to go through, probably for the sixth time, a series of about one hundred specimens of Crocothemis. They were attacked primarily with the idea of finding specific, or strongly racial, characters in the specimens above referred to, and secondly to test the possibility of separating C. servilıa and C. erythroea. Neuration and the genitalia of the second segment were especially examined.

It is easy to say that large examples from Hong Kong or Japan are servilia, and that smaller ones from Europe, Africa, India, \&c. are erythroca, and it is tolerably easy to isolate examples intermediate as to size, such as those from Moupin \&c. ; but once again have I failed to find any certain structural characters. There are slight neural differences, but only such as are either individual or correlated with size, and there 
are slight differences in the genitalia even in individuals from the same locality, but in the majority of cases of a nature more illusory than real. Some other investigator may be more fortunate.

\section{Subfam. Gomphina.}

Gomphus scissus, sp. n.

9. Head shining black; a spot on each side of the face at the corners of the mouth, a rather broad transverse band at the top of the front, and a small triangular spot at the back of the middle of the occiput yellow ; occiput strongly ciliated, produced in its middle into an erect flattened tooth, which is broad and triangular at its base, but afterwards strongly acuminate, the apical portion narrow, the apex itself obtuse and slightly bifid. Prothorax black, with a transverse nearly interrupted median spot, followed by a short line. Thorax black above, with grey pilosity, anteriorly with two transverse yellow lines (forming the collar), separated by the dorsal crest; behind these is an oblique isolated short yellow band on either side of the dorsal crest, and a small isolated yellow spot below each band placed more outwardly; two small yellow dots in the sinus; in the interalar area are three yellow spots: sides yellow, a black line on the interalar suture, connected anteriorly with a much angulated black line which extends nearly across the pectus, which latter is otherwise yellow. Legs short, wholly black. Abdomen dilated at the base, but afterwards slender, black, marked with yellow as follows:-above, a transverse spot on the first segment, followed by a median longitudinal band on the second; a fine interrupted dorsal line on the third, continued as a short basal line on the fourth to seventh, and a narrow ring at the apex of the ninth. Sides marked as follows :-a broad band on the first and second segments, continued as a narrower band on the third (interrupted in the middle by the false suture), a small basal and postmedian spot on the fourth to eighth, and the lateral margins of the eighth and ninth. Appendages about as long as the tenth segment, cylindrical, acute, yellow, tipped with black, a rounded black protuberance between them ciliated with black. Vulvar scale two thirds the length of the ninth segment, black, divided almost to the base into two long slender parallel spines, the apices of which are slightly upcurved.

Wings hyaline, strongly tinged with yellow to beyond the triangles in the anterior, and nearly up to the nodus in the 
costal portion of the posterior; neuration black; pterostigma long ( $3 \frac{1}{2}$ millim.), yellowish brown; 14 antenodal and 13 postnodal nervules in the anterior wings.

Length of abdomen, o 40 millim.; length of posterior wing, $q 35$ millim.

Siao-Lou (Szechuen), one female.

Notwithstanding that the male remains unknown, there can be little doubt that this species is allied to $G$. melcenops, Selys, and G. Pryeri, Selys, both from Japan. Both of these show an analogous conformation of the occiput, but in a much less pronounced manner, and are of the same general aspect but larger. The condition of the vulvar scale in G. scissus is remarkable.

\section{Subfam. CoRdULEGASTRINA.}

Anotogaster Sieboldii, Selys.

Moupin, one male, two females.

These seem to possess some slight differences when compared with numerous examples from Japan and North China. The two yellow spots at the base of the labrum are apparently smaller; the yellow in the excavated portion of the top of the front is reduced to a mere marginal thread (virtually obsolete in one very adult female), and the wings of the female seem more strongly washed with yellow up to the triangles, almost as in A.nipalensis and $A$. basalis. Possibly the stature is slightly less robust. It would be necessary to see more materials before deciding if the differences alluded to are constant and worthy of the imposition of a varietal name.

Cordulegaster luniferus, Selys, and var. pekinensis, Selys.

Four males and two females from Siao-Lou, Mo-si-mien, and other localities in Szechuen. Of these I should be inclined to refer three males to luniferus and one male and two females to pekinensis, irrespective of locality, according to description. Having now so much more material before me, the distinctness of luniferus and pekinensis seems very doubtful. I have seen no male so large as is indicated for pekinensis.

Subfam. AEsCHNina. AEschna ornithocephala, sp. n.

d. Head: labium and palpi brownish; labrum and face 
uniformly pale greenish yellow, margined with blackish at the summit; top of the front excavated, its margin broadly blackish, which colour descends in the middle, forming a very ill-defined $\mathrm{T}$-spot, the blackish colour blending with somewhat livid side-spots; vesicle black; eyes connected in a long space, occiput forming a small black triangle. Thorax black, above with two broad greenish-yellow bands, interrupted posteriorly by the sinus; the sides with two broad oblique greenish-yellow bands, one under each wing; probably some pectoral yellowish spots. Legs black. Abdomen with the first and second segments considerably dilated; oreilettes not prominent, flattened, yellow, with about three blackish marginal teeth; general colour dull blackish, becoming deeper black towards the apex, with indications of livid (blue or green during life?) markings as follows:- a broad lateral band and an indistinct dorsal band on first and second segments, a narrow margin posteriorly to the second to sixth, a broader submedian band (or semiannulus) on the third to eighth placed just below the false suture; tenth segment above with a rather strong longitudinal median carina, dilated posteriorly into a very strong laterally flattened triangular tooth directed slightly towards the apex. Superior appendages scarcely so long as the ninth and tenth segments united, black; viewed from above they are narrow at the base, afterwards gradually dilated internally to the apex, which is very obtuse and slightly excavated, the opposing apices tonching; the median longitudinal carina only faintly indicated, merging into the thickened apical portion; the inner edge fringed with long blackish hairs in the median portion: viewed laterally these appendages are straight, narrow at the base; subsequently the upper and lower edges form carinæ, the upper just before the apex becoming suddenly dilated and rounded (excavated above), and the lower ends in a short beak-like process, slightly upcurved, causing the entire apex to have a striking resemblance to the profile of the head of some kind of bird (e.g. Regulus, with the crest not erected). Inferior appendage fully two thirds the length of the superior, gradually acuminate, its apex apparently entire, slightly upcurved if viewed laterally; above deeply concave and brownish black, beneath black.

Wings hyaline; membranule white; pterostigma black, small ( $3 \frac{1}{2}$ millim. in anterior, shorter in posterior wings), surmounting $2 \frac{1}{2}$ cellules; neuration black; anterior wings with 18 antenodal and 12 postnodal nervules, 2 supra-trigonal, 
2 in the triangle; post-trigonal cellules commencing singly, then two rows, followed by three, and increasing; subnodal sector furcating on a level with the pterostigma (slightly before in the posterior); posterior wings with 12 ante- and postnodal nervules; 2 supra-trigonal and 2 in the principal triangle; anal triangle with 3 cellules.

Length of abdomen (cum append.) 54 millim.; length of posterior wing 48 millim.

Moupin, one male.

It is probable that the nearest ally of this well-marked species is the Japanese $\mathscr{E}$. melanictera, Selys, which it resembles in the possession of the strong tooth on the tenth segment, and there is some amount of affinity in the structure of the apex of the superior appendages; but the small size, very small pterostigma, much shorter appendages \&c. of the present insect are opposed to any very close relationship. The remarkable bird's-head-like profile of the end of the superior appendages is reproduced to some extent in the European $\not E$. cyanea and the North-American $A$. constricta, but neither of these has the tooth on the tenth segment.

N.B.-The female from Ta-chien-lu referred doubtfully to $Z E$. juncea in my former paper has no relationship to the present species, and was probably correctly referred.

\section{Subfam. CALOPTERY YINA. \\ Calopteryx Oberthüri, M'Lach.}

One female is from Siao-Lou, in the same district as Tachien-lu.

\section{Matrona basilaris, Selys.}

Nearly thirty examples of both sexes from Siao-Lou, Mosi-mien, Moupin, and other places in the district, all pertain to the type form and not to the race nigripectus, Selys.

\section{Archineura incarnata, Karsch.}

One adult female from Siao-Lou. As this sex has not been described, I append a description, omitting points common to both sexes:-

. Labrum pale yellow, with a narrow black border and a black line at the base, emitting a central prolongation not extending across. Colour of the body brighter green; a 
small yellow spot or line on the sides of the thorax above the insertion of each coxa, and a similar spot or line on each coxa itself externally; some small yellow spots under the insertion of the wings. Ninth and tenth abdominal segments slightly pulverulent; a median yellowish line on the dorsum of the ninth not reaching the extremities, and on this segment sligbtly before its apex there is a small median, nearly acute, conical tubercle, a slight median carina on the tenth; appendages shorter than the tenth segment, black, slightly divergent; vulvar lamina of the ninth ventral segment strong, broadly keel-shaped, its appendages black, filiform.

Wings hyaline, pale fuliginous, slightly tinged with olivaceous at the extreme base and along the costal margin to the nodus; neuration mostly reddish, the marginal nervures black, the costal nervure whitish pruinose externally; the nodal sector takes its origin slightly before the continuation of the nodal vein (in the male in my possession this sector arises distinctly after the nodal vein); pterostigma dull yellow between strong black veins (length 4 millim., broader than in the male); about 45 antenodal nervules in the anterior wings.

Length of abdomen 60 millim.; length of posterior wing 53 millim.

Considerably larger than the male, with no trace of the red base of the wings so conspicuous in that sex. The colour of the neuration and of the pterostigma resembles that seen in the very immature male described by Kirby as $A$. basilactea.

\section{Vestulis smaragdina, Selys.}

One very adult female from Moupin. It differs somewhat from the description and from specimens from the Khasia Hills in my collection. The size is larger (abdomen 43 millim., posterior wing 40 millim.). The abdomen above is metallic blue rather than green, with the ninth and tenth segments conspicuously whitish-pulverulent. The legs (excepting at base) nearly blackish, with the femora brown internally. Wings hyaline, with scarcely any trace of reddish tinge, but slightly olivaceous at base and along costal margin ; neuration almost blackish, dark brown in certain lights. It is probable that most of the differences above noticed (excepting that of size) are due to the individual being highly mature.

Caliphoea consimilis, M'Lach.

Four females, two from Siao-Lou and two from Moupin. 
These offer no peculiarities other than in abdominal sexual characters. In less highly mature examples the terminal segments of the abdomen are not pruinose above and the wings are simply hyaline, with no olivaceous tinge. Possibly the pterostigma is slightly shorter than in the male. The point of insertion of the nodal sector is slightly variable in different individuals, and there is sometimes only one nervule in the quadrilateral of the hind wings (in one individual there is only one such nervule in the right anterior and left posterior wing and two in the other wings).

Length of abdomen 33-35 millim.; length of posterior wing 31-33 millim.

\section{Subfim. Agriontan. \\ Mesopodagrion, g. n. (légion Podagrion).}

Nodus placed at one third the distance from base to pterostigma. Pterostigma short-oblong, dilated, surmounting three cellules. Quadrilateral with its upper edge two thirds the length of the lower, so that the outer edge is strongly oblique. Wings ceasing to be petiolated before the basal postcostal nervule, which is near the level of the second antenodal. Arculus coincident with the second antenodal. Postcostal area with one row of cellules. Subnodal sector commencing from the prolongation of the nodal vein, the median markedly before. Two supplementary sectors between the ultranodal and nodal sectors and between the nodal and subnodal, one between the median and short sectors.

Labium deeply divided, the lobes distant, subacute at apex. Second joint of antennæ somewhat longer than first. Abdomen moderately stout, cylindrical. Superior appendages of male longer than tenth segment, forcipate. Legs moderate, stout, spines long, claws minutely toothed below apex.

Having the facies of Argiolestes, but with a single row of postcostal cellules, and distinct from all Old-World forms of the légion in consequence of the wings ceasing to be petiolated before the basal postcostal nervule.

\section{Mesopodagrion tibetanum, sp. $\mathrm{n}$.}

o. Black; head clothed with rather long greyish hairs; labrum, a spot on each side of it, and another spot on each side below the base of the antennæ greenish yellow; two minute oblique lines (one on each side of the ocelli) and a short line on the middle of the occiput yellowish; a large 
yellow spot behind each eye. Prothorax with a yellow line on each side (continuous with the humeral lines). Thorax with a slightly curved, rather broad, humeral yellow line; sides and pectus yellow, divided by a nearly straight black line, broadest anteriorly. Legs black; coxæ and trochanters spotted with yellow. Abdomen clothed with rather long black hairs at its base, somewhat shining; first segment broadly yellow at sides, second with two yellow lateral lines, third and fourth with one yellow lateral line (not reaching the apex on the fourth), and with a yellow lateral basal spot; ninth and tenth segments probably sometimes pulverulent above, tenth broadly produced into a triangle on its posterior margin, deeply cleft in its middle, yellow on its sides. Superior appendages longer than the tenth segment, subcylindrical, gradually forcipate, the incurved apices acute, not toothed; inferior appendages indicated by a brown swollen base, divided by a line in its middle, filling in the wide excision in the tenth ventral segment.

Wings vitreous, slightly tinged with smoky yellowish; pterostigma (3 millim.) dark reddish brown, between strong black nervures; neuration black; 21 postnodal nervules in the anterior wings, 20 in the posterior.

$q$ as in the male, but the labrum and the spots on the front are livid or brownish and the spot behind the eyes is absent or obsolete. Abdomen more shining; a single yellow lateral line on the second segment, continued on the third and fourth, and an apical yellow lateral spot on the third to seventh; ninth with a very large yellow lateral spot, and the tenth largely yellowish on the sides. Appendages as long as the tenth, slightly curved laterally, acuminate, pointed, yellowish at the base; viewed in front there is a large swollen yellow sulcate mass between their base; appendages of vulvar lamina cylindrical, black, strongly curved.

Wings scarcely tinged; pterostigma (slightly immature) whitish yellow; neuration brownish in certain lights; 21 postnodal nervules in anterior wings, 19 in posterior.

Length of abdomen, $\delta 33$, $q 35$ millim.; length of posterior wing, os 30 , \& 34 millim.

Moupin, one male; Siao-Lou, one female.

\section{Pyrrhosoma tinctipenne, $\mathrm{M}^{6}$ Lach.}

Erythromma tinctipennis, M'Lach. Ann. \& Mag. Nat. Hist. ser. 6, vol. xiii. (May 1894) p. 436.

The discovery of the male renders it certain that this insect is a Pyrrhosoma rather than an Erythromma (the two genera 
being defined by scarcely more than colour differences). The single example is from Siao-Lou, in the same district as the locality whence came the females.

$\delta$. Head and thorax as in the female, the pale lines on the thorax more reddish. Abdomen much more slender, bright red; first and second segments yellowish at sides and beneath; a large black subquadrate mark on the first segment above, and the posterior margin of this segment and also of the third is narrowly black; an isolated line on the sides of the seventh not reaching the margins, a thicker and shorter line on the eighth reaching the anterior margin only, and a quadrate spot on the ninth (also reaching the anterior margin) all black; an indication of a paler (yellowish?) dorsal spot at the base of the seventh, and the ninth and tenth also paler; margin of the tenth shallowly excised in its middle. Appendages reddish yellow, longer than the tenth segment; superior appendages subcylindrical, inserted distantly, somewhat divergent, broader at base, the apices somewhat suddenly incurved and blackish; inwardly at the base is a short slender branch or tooth inserted at nearly a right angle; inferior appendages broader and slightly shorter, their tips incurved and obtuse if viewed laterally.

Wings tinged as in the female; pterostigma somewhat more reddish ; 4 antenodal cellules, $15-16$ postnodal nervules in the anterior wings.

Length of abdomen $27 \frac{1}{2}$ millim.; length of posterior wing 21 millim.

This is the analogue of the European P. minium rather than of $P$. tenellum. Both these species have a form of the female in which the abdomen is nearly wholly black or blackish; and it seems quite possible that a form of that of $P$. tinctipenne may be discovered in which the abdomen is in part red.

$$
\text { Ceriagrion melanurum, Selys. }
$$

Moupin, three males, one female.

LII.-Descriptions of Two new Species of Butterflies from New Britain. By H. Grose Smith, F.E.S., F.Z.S., \&c.

\section{Tachyris maculata.}

Male.-Upperside. Both wings white: anterior wings with costal and outer margins black, the latter rather broadly and 